Academic Platform Journal of Engineering and Science

\title{
Tersine Lojistik Bakış Açısı ile Katı Atık Yönetiminin İstatistiksel Değerlendirmesi: Karabük Bölgesi Demir Çelik Sektör Analizi
}

\author{
${ }^{* 1}$ Tuğba Tunacan, ${ }^{2}$ Tuğba Nizam, ${ }^{3}$ Burcu Tezcan \\ ${ }^{1}$ Endüstri Mühendisliği Bölümü, Mühendislik Fakültesi, Abant İzzet Baysal Üniversitesi, Türkiye, tugbatunacan@ibu.edu.tr, \\ ${ }^{2}$ Endüstri Mühendisliği Bölümü, Mühendislik Fakültesi, Karabük Üniversitesi, Türkiye, tubanizam14@ gmail.com, \\ ${ }^{3}$ Endüstri Mühendisliği Bölümü, Mühendislik Fakültesi, Karabük Üniversitesi, Türkiye, buurcutezcan@ gmail.com, \\ Araştırma Makalesi \\ Geliş Tarihi: 05.02.2019 \\ Kabul Tarihi: 11.10 .2019
}

Öz

Tersine lojistik, girdisi çoğunlukla çevre yönünden zararlı atıklar veya yeniden değerlendirilebilecek ıskartaya ayrılmış ürün, yarımamül ve hammadde olan bir yeniden dönüşüm sürecini içeren faaliyetler bütünüdür. Genellikle sadece kullanılmış ürünlerin belli bazı özelliklerinin süreçte yenilenerek yeniden kazandırılması şeklinde düşünülmesine rağmen tersine lojistik faaliyet alanı bakımından hem çevresel yönü açısından hem de işletme alanı tarafından önemli bir araştırma alanıdır. Tersine lojistik uygulamalarına dünya çapında yapılan yasal düzenlemeler ve destekler arttırıldığı bilinmektedir. Bunun en büyük nedeni bu uygulamalar ile enerji üretimi ile atıkların yeniden dönüşümü olduğu söylenebilir. Demir çelik sektörü de hem atık üretimi hem de katı atıkların kullanımında başta gelen sektörlerden biri olduğu için tersine lojistik için uygun bir çalışma alanıdır. Biz de çalışmamızda tersine lojistik kavramının odak noktası haline gelen atık ürünlerin değerlendirilmesi konusunda demir-çelik sektörünün ne kadarının bilinçli olduğunu araştırmayı amaçladık. Pilot bölge olarak Karabük ili çevresinde faaliyet gösteren 22 demir-çelik fabrikası seçilmiş olup 27 sorudan oluşan anket ile frekans analizi ve tek örneklem t-testi ile bu amacımız değerlendirilmeye çalışılmıştır.

Anahtar Kelimeler: Tersine Lojistik, Demir-Çelik Sektörü, Atık Yönetimi, Frekans Analizi, Tek Örneklem t-Testi

\section{Statistcal Evaluation of Solid Waste Management from Reverse Logistic Perspective: the Iron and Steel Sector in Karabuk Province}

\begin{abstract}
The reverse logistic is a process of recycling, in which input is often environmentally harmful waste or recycled product, semifinished and raw material. The scope of reverse logistic is an important research area both in terms of environmental aspect and business area in terms of reverse logistics area although it is thought that only certain attributes of used products are refunctioned by being renewed in production process. Also, it is known that Worldwide legal regulations and supports of reverse logistic applications are increased because of energy production and recycling of waste. The iron and steel sector is a recycling area for both waste production and use of scrap (metal waste). In our study, we aimed to assess how much of the iron and steel industry is aware of the waste products that have become the focus of the reverse logistics concept. 22 iron and steel factories operating in Karabük province were selected as the pilot region. Data was collected by using a survey consisting of 27 questions. The aim of our study was evaluated by frequency and one sample t-test analysis.
\end{abstract}

Keywords: Reverse Logistic, Iron and Steel Sector, Waste Management, Frequency Analysis, One Sample t-test

\section{GİRIŞ}

Tersine Lojistik, endüstriyel faaliyetlerin artması ile birlikte meydana gelen iklim değişiklikleri, hava, toprak ve su kaynaklarında meydana gelen kirlilik oranın artışı nedeniyle çevresel yönetimler ve işletmeler arasındaki etkileşim sebebiyle ortaya atılan bir araştırma alanıdır [1]. Bu araştırma alanı tedarik zinciri yönetimi ve lojistik çalışma alanı ile birlikte çalışmalar yapılmış olsa da yapısı ve çalışma kavramları itibari ile farklı bir yapıya sahiptir. Tersine lojistik daha çok geri dönüşümü, yeniden üretimi veya yok edilecek ürünlerin veya parçaların tüketim noktasından ilk üreticisine sistematik olarak toplanması süreci olarak tanımlanmaktadır [2,3]. Tersine lojistik aynı zamanda bir

${ }^{* 1}$ Corresponding author: Faculty of Engineering and Architecture, Department of Industrial Engineering, Abant Izzet Baysal University, 14030 , Bolu TURKEY. tugbatunacan@ibu.edu.tr, Phone: +903742534558/4901

Bu çalışma ISEM2018 sempozyumunda "141" başlıklı bildiri olarak sunulan çalışmadan geliştirilmiştir. 
imalatçıdan, dağıtıcıdan veya kullanım noktasından kurtarma noktasina veya uygun kullanım noktasına hammaddenin, yarı mamulün, paketlenmiş veya bitmiş ürünlerin geriye doğru akışını planlama, uygulama ve kontrol etme süreci olarak da tanımlanabilir[4].

Lourenço ve Soto (2002) yayınladıkları bir çalışmada tersine lojistik kavramı ile ilgili yapılan tanımların unsurlarını bir tablo halinde toparlamış ve bu durum tablo 1 de sunulmaktadır [5]. Tablo 1. de görüldüğü gibi tersine lojistikte girdiler imalat anlamında baktığımızda önceden kullanılmış veya imalat sırasında hata nedeni ile hurdaya çıkan ürünleri kapsarken çevresel boyutta ise tehlikeli olan ya da olmayan atıklar, paketler ve ürünleri kapsamaktadır. İmha edilmesi gereken ürünler haricinde diğerleri yapılan yeniden düzenleme ve gerekli olan imalat işlemleri ile birlikte tekrar kullanım için tüketicilere yeni ürün olarak sunulmaktadır.

Tablo 1. Tersine Lojistik Tanımlarında yer alan Girdi-İșlemÇıktı Kavramları [5]

\begin{tabular}{|l|l|l|}
\hline Girdi & İşlemler & Çıktı \\
\hline Hurda ürünler & Toplama & Geri \\
Kullanılmış ürünler & Nakliye & Kazanılmış \\
Tehlikeli olan ya da & Depolama & ürünler \\
olmayan atıklar & Parçalara ayırma & İkinci \\
Önceden gönderilmiş & Kabul & Kalite \\
ürün ya da parçaları & Yeniden İşleme & ürünler \\
\hline
\end{tabular}

Avrupa, $\mathrm{ABD}$ ve Japonya ülkelerinde atıklardan kaçınma, yeniden imal etme ve kullanım ile atıkların kurtarılması ya da elektronik ekipman ve piller, kimyasal ürünler, cam, kağıt, plastik ve ağır metalleri içeren malzemelerin geri dönüşümünü destekleyen kanuni düzenlemeler mevcuttur. Özellikle Avrupa, tedarik zinciri veya tersine lojistik ağındaki imalatçı ve dağıtıcıları ürün-yaşam çevriminin sonuna gelmiş olan ürünleri, elektronik ve ambalaj atıkları, çevresel olarak tehlikeli ürünleri geri dönüşüm ve yeniden kullanım için destekleme konusunda başı çeken bir kıtadır [6].

Diğer üretim sektörlerinde olduğu gibi demir çelik sektörü de yapısı gereği hammadde ve enerji kullanımı ile atık üretimi yoğun olan bir sektördür. Bu sektör de birkaç farklı atık ortaya çıkmaktadır. Bunlardan en önemlisi üretim sırasında veya kullanıldıktan sonra 1skartaya çıkan hurda malzemeler ve bacalarda oluşan tozlardır. Hurda malzemeler yeniden çelik üretiminde kullanılmakta, diğeri ise lisanslı geri kazanım firmaları ile içerisinde bulunan önemli mineraller geri kazanılmaktadır. [7]. Bu sebeple birçok ülke de çelik malzemelerin geri dönüşümü hurda toplama programları, demir hurda işleyicileri, haddehaneler ve imalatçılardan ve aynı zamanda dönüştürülmüş çeliğe ait çoklu pazarlar ile birlikte iyi bilinen bir tedarik zinciri ağ olarak tanımlanmaktadır [8]. Tersine lojistik uygulanarak çelik hurda malzemesinin elde edilmesi ve sonra yeniden üretilerek pazara sunulması demir cevherini kullanarak üretim yapılmasından daha az maliyetli olduğu söylenebilir. ABD çelik geri dönüşüm kurumu (2006a) 2005 yllı için yayınladığı raporunda $\% 76$ oranında bir çelik geri dönüşüm değerine sahip olduklarını raporladı. Bu orandaki çelik geri dönüşümünden \% 74 oranında enerji kazancı elde edildiği, $\% 97$ oranında madencilik atıklarında, \% 88 hava emisyonunda, \% 76 su tüketiminde azalma ile hem çevresel hem de ekonomi bakımından kazançlar elde edildiği bildirilmiştir. Buna ek olarak üçüncü dünya ülkeleri geliştikçe ve tüketim miktarı arttıkça demir cevheri, alüminyum, bakır ve petrol gibi hammaddeler de tedarik konusu sıkıntılı hale düşecektir [6]. Bunun için yeni ürün pazarları Spengler (1997), Almanya çelik endüstrisinde endüstriyel ürünlerin geri dönüşümü için model geliştirmiştir. Modelde negatif çevresel etkileri azaltmak ve atık maliyetlerinden kaçınmak amaç edinilmiş̧ir [9]. Türkiye çelik üreticileri tarafindan geri kazanım konusunda yeni teknolojilere adım atıldığı bildirilmektedir.

Biz de çalışmamızda tersine lojistik kavramının odak noktası haline gelen atık ürünlerin değerlendirilmesi konusunda demir-çelik sektörünün ne kadarının bilinçli olduğunu araştırmayı amaçladık. İkinci bölümde araştırma metodolojisinden ve sinırlılıklarından bahsedilecektir. 3 . Bölümde ankete verilen cevapların istatistiksel olarak sonuçları ve son bölümde ise sonuçlar tartışılacaktır.

\section{ARAȘTIRMA METODOLOJİSi}

Bu bölümde çalı̧̧maya ait örneklem ve anket ile ilgili kısıtlar ve anket formunun hazırlanmasında dikkate alınan literatür çalışmalarına yer verilecektir. Çalı̧̧maya dair en önemli kısıt anket yapılmış olan işletmelerin anket sorularına verdikleri cevapların doğru olduğunun varsayılması ile ilgilidir.

Çalışmamız pilot uygulama çalışması olup odak noktası Karabük ilinde faaliyet gösteren firmaları kapsamaktadır. İl kapsamında sektör olarak tekstil, turizm ve demir-çelik üretim sektörü arasından ağırlıklı olarak demir-çelik üretimine yer verilmesinden dolayı çalışma evreni olarak seçilmiştir. Toplam da faal anlamda 22 firma bulunmaktadır ve tamamına yüz yüze anket yolu ile veri elde edilmeye çalışılmıştır. Anketlerde değerlendiren kişiler tarafindan eksik bırakılan soru grubu olmadığından ve aynı zamanda gürültü faktörü yaratacak herhangi bir anket olmadığından dolayı toplamda 22 farklı işletmeden görüş değerlendirilmeye çalışılmıştır.

Anket sorularına ait ölçek Asar (2017) tarafindan yapılan çalışmadan faydalanılarak geliştirilmiştir. Asar tarafindan yapılan çalışma da ölçek 48 sorudan ve iki bölümden oluşmaktadır. İlk bölüm demografik özelliklerin tespiti için kullanılırken, ikinci bölüm tersine lojistik uygulandığında elde edilen faydaları ve uygulama da karşılaşılan zorlukları tespit etmek amaciyla sorulmuştur [10]. Bu ölçekten faydalanarak geliştirmiş olduğumuz anket ise toplamda 27 sorudan oluşmaktadır. Ölç̧eğimiz iki bölümden oluşmaktadır. Birinci bölüm tersine lojistik kavramları hakkında işletmelerin bilgisini ölçmek amacıyla 
geliştirilmiştir. İkinci bölüm ise maliyet, kalite, çevre ve atıkların değerlendirileceğine dair kazanılan faydaları ve eksiklikleri tespit etmek amaciyla sorulmuş olup 5 li likert ölçeğine uygun olarak tasarlanmıştır.

\section{ANALIZZ SONUÇLARI}

Anket cevapları öncelikli olarak güvenirlilik analizi ile değerlendirilmiştir. İlk bölüm olan işletmelerin tersine lojistik konu kapsamı ile ilgili fikirlerini öğrenmek amacıyla sorulduğu için bu bölüme gelen cevaplar frekans analizi ile analiz edilmiştir. İkinci bölüm ile ilgili sorular hakkında bilgi edinmek amacıyla t-testi ve frekans analizi yapılmıştır. Tüm analiz sonuçları aşağıdaki bölümlerde sırasıyla açıklanmaya çalışılmıştır.

\subsection{Güvenirlilik Analizi}

27 sorudan ilk 5 soru tersine lojistik konusunda firmaların tanımlamaları ve atık değerlendirme konusunda kullandıkları yöntemler sorulduğu için bu sorular güvenirlilik analizinden çıkarılmıştır. 6 - 27 numaraya kadar olan sorular 5 li likert ölçeğine uygun sorulmuş olup güvenirlilik analizi bu sorulara uygulanmıştır ve tüm ankete ait güvenirlilik değeri 0,819 olarak hesaplanmıştır.

Tablo 2. Sorulara Ait Güvenirlilik Testi Sonuçları

\begin{tabular}{|l|l|l|l|l|l|l|}
\hline & \multicolumn{1}{|c|}{ Ortalama } & Std. Hata & $\begin{array}{c}\text { Silinirse Ölçek } \\
\text { Ortalamas1 }\end{array}$ & $\begin{array}{c}\text { Silinirse Ölçek } \\
\text { Varyans1 }\end{array}$ & \multicolumn{1}{|c|}{ Korelasyon } & $\begin{array}{c}\text { Silinirse } \\
\text { Cronbach- } \\
\text { Alpha }\end{array}$ \\
\hline Soru 6 & 4,09 & 0,426 & 80,18 & 87,680 & 0,103 & 0,820 \\
\hline Soru 7 & 4,09 & 0,610 & 80,18 & 85,965 & 0,207 & 0,818 \\
\hline Soru 8 & 2,50 & 1,012 & 81,77 & 83,613 & 0,219 & 0,820 \\
\hline Soru 9 & 4,05 & 1,133 & 80,23 & 81,327 & 0,297 & 0,817 \\
\hline Soru 10 & 4,14 & 0,640 & 80,14 & 85,647 & 0,222 & 0,818 \\
\hline Soru 11 & 2,91 & 1,192 & 81,36 & 77,766 & 0,452 & 0,808 \\
\hline Soru 12 & 3,27 & 1,420 & 81,00 & 76,667 & 0,402 & 0,812 \\
\hline Soru 13 & 3,73 & 1,202 & 80,55 & 84,926 & 0,104 & 0,828 \\
\hline Soru 14 & 4,14 & 0,468 & 80,14 & 85,171 & 0,382 & 0,814 \\
\hline Soru 15 & 4,27 & 0,883 & 80,00 & 77,524 & 0,668 & 0,798 \\
\hline Soru 16 & 3,55 & 1,184 & 80,73 & 73,922 & 0,656 & 0,795 \\
\hline Soru 17 & 4,32 & 0,568 & 79,95 & 84,522 & 0,368 & 0,813 \\
\hline Soru 18 & 4,14 & 0,889 & 80,14 & 88,695 & $-0,048$ & 0,830 \\
\hline Soru 19 & 3,32 & 1,427 & 80,95 & 76,236 & 0,418 & 0,811 \\
\hline Soru 20 & 3,32 & 1,041 & 80,95 & 78,522 & 0,492 & 0,806 \\
\hline Soru 21 & 3,95 & 1,046 & 80,32 & 76,894 & 0,583 & 0,800 \\
\hline Soru 22 & 4,14 & 0,834 & 80,14 & 80,219 & 0,520 & 0,806 \\
\hline Soru 23 & 3,95 & 0,899 & 80,32 & 78,799 & 0,569 & 0,803 \\
\hline Soru 24 & 4,32 & 0,646 & 79,95 & 80,807 & 0,642 & 0,804 \\
\hline Soru 25 & 4,55 & 0,510 & 79,73 & 81,541 & 0,748 & 0,804 \\
\hline Soru 26 & 4,55 & 0,510 & 79,73 & 81,351 & 0,769 & 0,803 \\
\hline Soru 27 & 3,00 & 1,024 & 81,27 & 85,255 & 0,126 & 0,824 \\
\hline
\end{tabular}

Güvenirlilik katsayısı analiz edilen veri grubundaki hata değerine göre farklılık göstermektedir. Hata durumuna göre 0 ile 1 değerleri arasında değer alır. En yaygın olarak kullanılan içsel güvenirlilik indeksi Cronbach Alpha değeridir [12]. Cronbach Alfa değeri ile ilgili değerlendirmeler aşağıdaki gibi verilebilir [13]

- $0,00<\alpha<0,40$ ise ölçek güvenilir değildir.
- $\quad 0,41<\alpha<0,60$ ise ölçek güvenilirliği düşüktür.

- $0,61<\alpha<0,80$ ise ölçek güvenilirliği kabul edilebilir seviyededir.

- $\quad 0,81<\alpha<1,00$ ise ölçek güvenilirliği yüksektir.

$\mathrm{Bu}$ durumda ölçeğimizin güvenirlilik puanına göre "güvenirliliği yüksek" kategorisinde olduğu söylenebilir. Her bir soruya ait güvenirlilik durumu tablo 2 de 
sunulmaktadır. Tabloyu incelediğimizde aşağıda ifade edilen sorular değerlendirilmeden çıkarıldığında anket güvenirlilik değerinin artacağını söylemek mümkündür. Bunlar sırasıyla;

- Soru 13. Ters lojistik uygulamaları işletmelere ürün ya da materyal edinim maliyetlerinde azalma sağlar
- $\quad$ Soru 18. Ters lojistik uygulamalarında; kullanılmış ürün, yeni ürün düzeyinde kalite özelliklerine sahip olmasını sağlayacak işlemlerden geçirilir.

- Soru 27. Ters lojistik faaliyetleri garanti kapsamından geri dönen ürünlere uygulanır.

Tablo 3. İşletmelere yöneltilen tersine lojistik soruları hakkında ki görüşlere ait Frekans Analizi

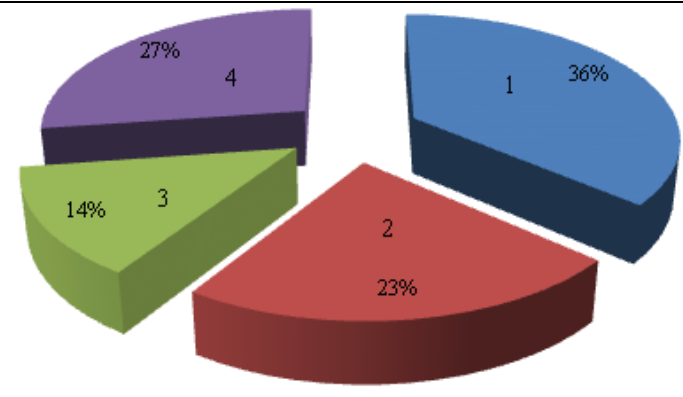

A. Soru 1: Tersine lojistik kavramının işletmeler tarafından tanımı

1. Geri Dönüşüm

2. Kullanılmış Ürünlerin Yeniden Kullanımı İçin Üretim Sürecine Doğru Tersine Akışı

3. Ürünlerin Çevreye Zararının En Aza İndirilmesi İçin Yok Edilmesi Amaciyla Toplanması

4. Geri Dönen Ürünler Ara. Kullan. Durumda Olanların Değer. Hammadde Kullanımını Azaltıp Ekonomik Açıdan Kazanç Sağlamak

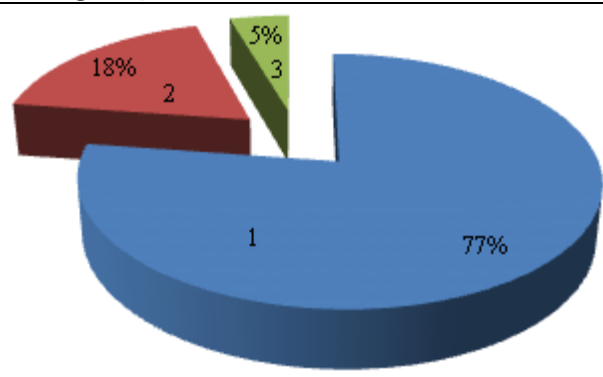

B. Soru 4: Tersine lojistik sürece dahil edeceğiniz ürünleri ne şekilde topluyorsunuz?

1. Doğrudan kaynağında alınarak

2. Tüketici toplama merkezlerinden alınarak

3. Dış kaynakları kullanarak

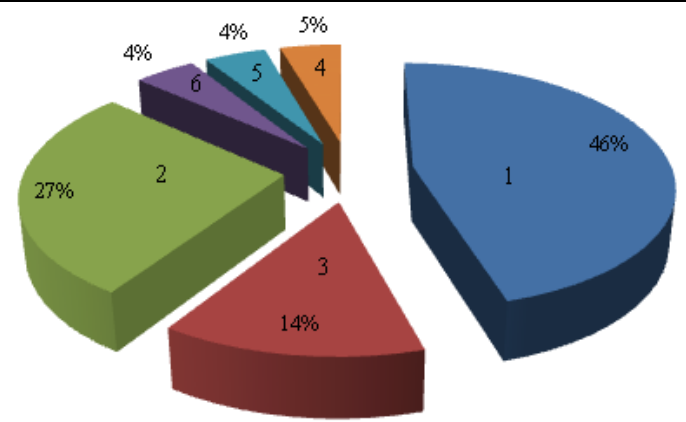

C. Soru 5: Geri dönüşüm için toplanan malzemelere tersine lojistik faaliyetlerden hangisini uyguluyorsunuz ?

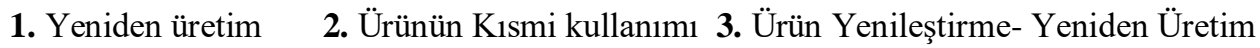

4. Yeniden Üretim-Yakma ve Gömme-Ürünün Kısmi Kullanımı

5. Yeniden Üretim-Yakma ve Gömme-Ayrıştırma-Ürünün Kısmi Kullanımı

6. Ürün Yenileştirme- Yeniden Üretim-Yakma ve Gömme-Ayrıştırma-Ürünün Kısmi Kullanımı

Ayrıca aşağıdaki üç sorunun ise mutlaka değerlendirme olması gereken soru kapsamında yer aldığını söylemek mümkündür. Diğer geri kalan soruların eklenip çıkarılması anketin güvenirliliğinde çok fazla değişime neden olmayacağı tespit edilmiştir. Mutlaka değerlendirmede bulunması gereken sorular sirasıyla;
Soru 15. Ters lojistik uygulamaları çevre kirliliğini en aza indirme açısından faydalıdır.

- Soru 16. Ters lojistik uygulamaları şirket imajında artış sağlar.

- Soru 21. Ters lojistik uygulamaları işletmeleri çevresel açıdan daha etkin olmasını sağlar 


\subsection{Frekans Analizi Sonuçları}

Tablo 3 "tersine lojistik" konusu temel kavramları ile ilgili sorulan sorulara işletmeler tarafindan verilen cevaplara ait frekans analizi sonuçları sunulmaktadır. Bu temel kavramlar, tersine lojistik tanımı (A Alanı), ürünlerin toplanma şekli (B Alanı) ve toplanan ürünleri dönüştürmek için uygulanan yöntemleri (C Alanı) içermektedir.

"a" sütunu incelendiğinde işletmelerin \% 36 sinın tersine lojistiği geri dönüşüm olarak algıladığ $1 \% 27$ sinin ise tersine lojistik için yapılan tam tanımı bildiği görülmektedir. \% 14 ü ise tersine lojistiğin çevre ile ilişkisini tanımlamıştır.

"b" sütunun incelediğimizde işletmelerin \% 77 sinin hurda ürünleri doğrudan kaynağından alarak topladığ 1 görülmektedir. "c" sütununu incelediğimizde işletmelerin \% 46 sının topladıkları ürünlere yeniden üretim yaparak yeni ürüne dönüştürme işlemi yaptığı görülmektedir. Bunu \% 27 si ile ürünün kısmi kullanımı ve \% 14 ile ürün yenileştirmeyeniden üretim fonksiyonları izlemektedir. Tüm \% lik değerlere ait seçeneklere baktığımızda işletmelerin neredeyse tamamının "yeniden üretim" fonksiyonunu seçtiğini sadece \% 46 sının sadece bu seçeneği seçtiğini söylemek mümkündür.

Tablo 4 işletmelerin hangi atıkları değerlendirmek için topladığına dair sorulmuş olan sorunun cevaplarını sunmaktadır. Bu soru da "Soru 5" de olduğu gibi aynı anda birden fazla seçeneğin seçildiği sorudur. İşletmelerin \% 95.5 inin metal atıkları değerlendirmek için topladığı ancak \% 59.1 inin sadece metal atığı toplayıp değerlendirdiğ görülmektedir. Bunu \% 18.2 ile metal atık ile birlikte plastik ambalaj ve akü veya pil atıklarına ait sonuçlar izlemektedir. Sadece 1 işletme demir çelik sektöründe olup kağıt ve tekstil ürünlerine ait atıkları topladığı belirlenmiştir.

\section{3 t-Testi Sonuçları}

Anketimizde demografik özellik bakımından farklılıkları ölçmek maksadı ile soru sorulmadığından dolayı tek örneklem t-testi yapılmıştır. Ayrıca değerlendirilen atık cinsi ve değerlendirme yöntemlerine ait sorulara verilen cevaplara ilişkin frekans analizi sonuçlarında farklılık değerlendirmesi için yeteri derece de değişken frekans değerlerine sahip olmadığı görülmektedir. Tek örneklem t-testi sonuçları tablo 5 de sunulmaktadır.

Tablo 4. Değerlendirilen Atıklara Ait Frekans Analizi

\begin{tabular}{|l|l|l|l|}
\hline & Frekans & \% & Kümülatif \% \\
\hline Metal & 13 & 59,1 & 59,1 \\
\hline Metal/Kağıt/Aküpil & 1 & 4,5 & 63,6 \\
\hline Plastik Ambalaj/ Metal/Aküpil & 4 & 18,2 & 81,8 \\
\hline Plastik ambalaj/Metal/Kağıt/Aküpil & 1 & 4,5 & 86,4 \\
\hline Cam Şişeler/Plastik Ambalaj/Metal/Kağıt/Aküpil & 1 & 4,5 & 90,9 \\
\hline Plastik/Metal/Elektronik atıklar/Aküpil & 1 & 4,5 & 95,5 \\
\hline Kağıt/Tekstil & 1 & 4,5 & 100,0 \\
\hline
\end{tabular}

Tablo 5 incelendiğinde 5 li likertte "kararsız seçeneği - 3 puan" olarak kabul edilen değere göre analiz yapıldığında tüm sorular için $p$ değerlerine bakıldığında genelinin ortalama puandan farklı olduğu gözlemlenmektedir. Tablo da ortalama sütununa bakıldığında "Dönüştürülmüş ürünlerin kullanımı kalitesi nedeniyle müşterisi az olan ürünlerdir (Soru 8)" sorusuna verilen cevapların test değeri "3" den daha az olduğu görülmektedir. Bunun nedeni sorulan sorunun yönünün ters yönde olmasından kaynaklandığı da soru tipine bakıldığında anlaşılmaktadır.
$\mathrm{Bu}$ durumda atıklardan geri kazanılmış ürünlerin müşterisinin diğer yöntem ile elde edilmiş ürünlerin müş̧eri kadar olduğu yorumu yapılabilir. Ayrıca 11, 12, 19, 20 ve 27 no' lu sorular için işletmelerin verdiği cevaplara ait ortalamaların 3 veya 3 e çok yakın bir değer olduğu görülmektedir. $\mathrm{Bu}$ sorular için işletmelerin bu sorulara tam kesin anlamda bir cevap oluşturamadığı bu yüzden kararsız kaldığı söylenebilir. 
Tablo 5. Test Değeri= 3 olma durumuna göre Tek Örneklem t-Testi Sonuçları

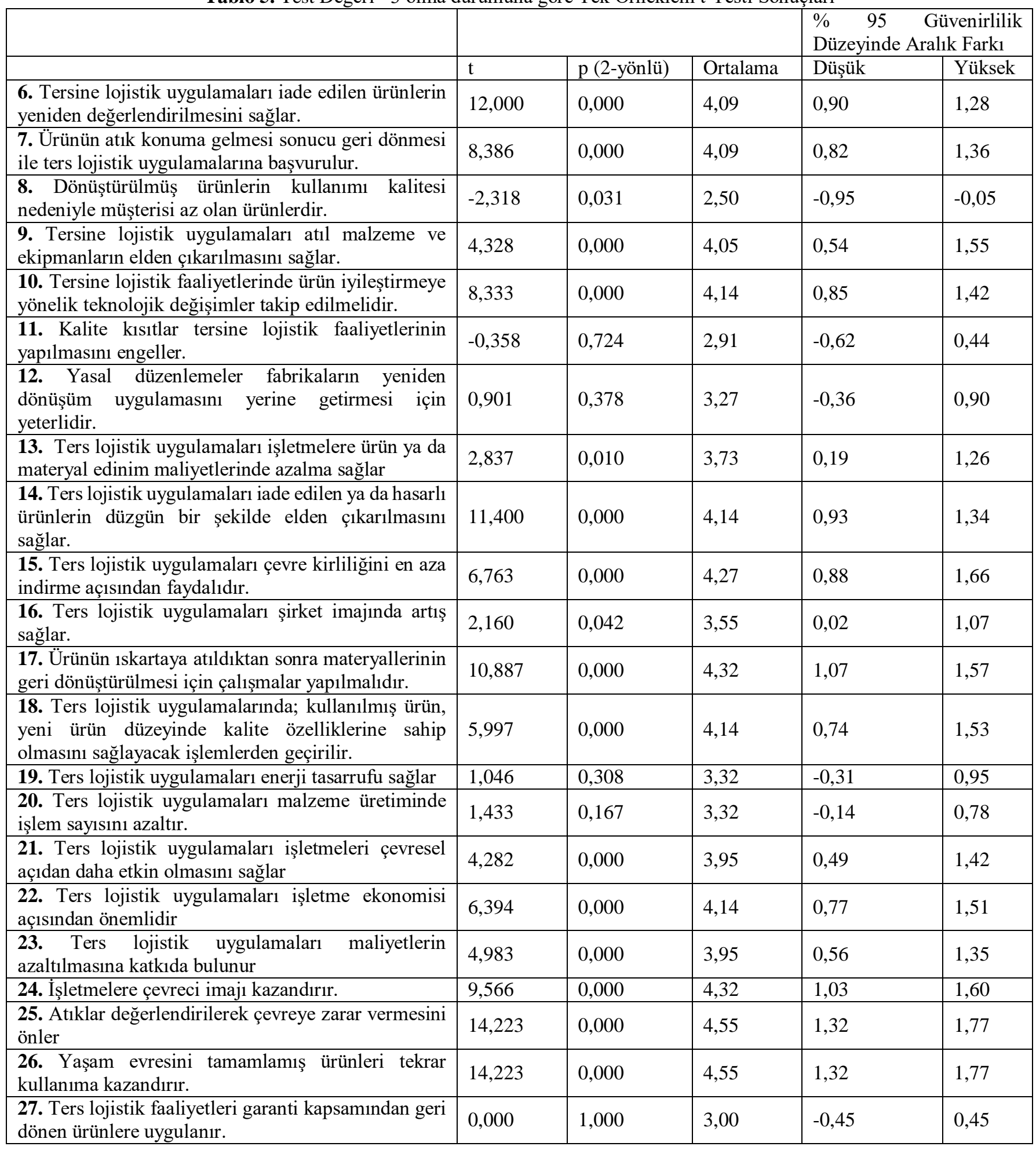

Tablo 6 güvenirlilik analizi sonucunda değerlendirilmesi gereken sorular kapsamında bahsedilen soru 15 (B Sütunu) soru 16 (C Sütunu) ve soru 21 (D Sütunu) soruları için yapılmış frekans analizlerini göstermektedir. Ayrıca tablo soru 12 (A Sütunu) atıkların değerlendirilmesi konusunda yasal düzenlemelerin yeterliliği açısından değerlendirme sonuçlarını da içermektedir. A sütununu incelediğimizde yaklaşık olarak işletmelerin \% 45 inin (hem katılıyorum hem de tamamen katılıyorum \% değerleri) yasal düzenlemelerin yeniden dönüşüm konusunda kendilerini desteklediğini belirttikleri görülmektedir. \% 23 kararsız kalırken \% 32 sinin ise yeterince desteklemediği yönünde görüşe sahip olduğu gözlemlenmiştir. Özellikle kararsız-katılmıyorumhiç katılmıyorum kapsamında değerlendirme yaparsak işletmelerin büyük bir çoğunluğunun yasal düzenlemelerin 
yeniden dönüşüm konusunda kendilerini yeterince desteklemediğini söylemek mümkündür.

Tablo 6. Temel Seçilmiș Sorulara ait Frekans Analizi Sonuçları

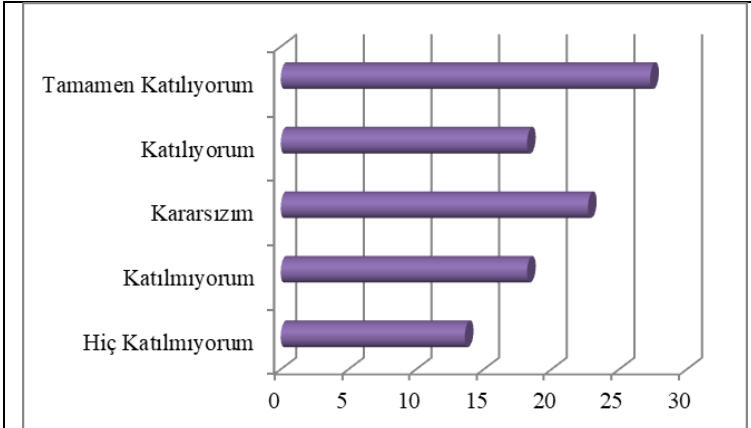

A. Soru 12: Yasal düzenlemeler fabrikaların yeniden dönüşüm uygulamasını yerine getirmesi için yeterlidir.

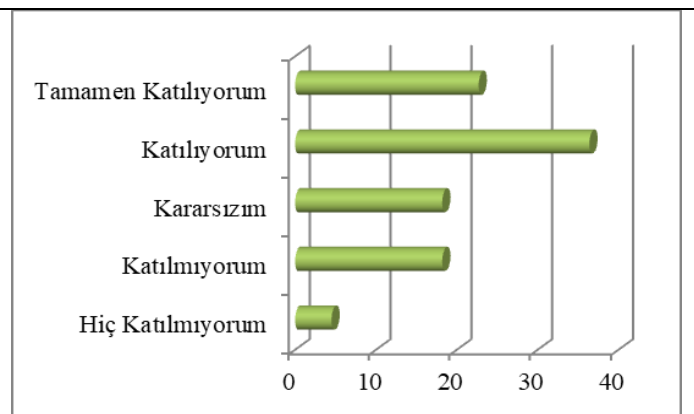

C. Soru 16: Ters lojistik uygulamaları şirket imajında artış sağlar.

B sütununu incelediğimizde işletmelerin $\% 82$ sinin tersine lojistik uygulamalarının çevre kirliliğini en aza indirmesi açısından faydalı bir uygulama olarak değerlendirdiği gözlemlenmiştir. D sütunu ise Soru 15 gibi işletmelerin \% 73 ünün tersine lojistik uygulamalarının kendilerine çevresel açıdan daha etkin olmasını sağladığını gösteren frekans analizi sonuçlarını içermektedir. Bu durumda tersine lojistik uygulamalarının $\mathrm{C}$ sütunu frekans analizi sonuçları (yaklaşık $\% 601$ şirket imajını arttırdığı) soru 24 için t-testi sonuçlarına (ortalama: 4.32) da bakılarak işletmelere çevreci bir imaj kazandıracağ 1 ve toplanan atıkların yeniden değerlendirilmesi ile özellikle "metal sektöründe" yaşanan hammadde kaynağı kısıtını da azaltacağı yönünde yorum yapılabilir.

\section{SONUÇLAR}

Karabük Valiliği çevre ve şehircilik il müdürlüğü tarafindan hazırlanan Karabük ili 2016 çevre durum raporuna göre birinci öncelikli çevre sorununun haddehanelerden ortaya çıkan atıklar nedeni ile hava kirliliği olduğu bildirilmektedir. Üçüncü derecede önemli sorunun ise il çevresinde düzenli bir katı atı toplama-depolama sisteminin yani bir tersine lojistik faaliyetinin olmadığı aynı zamanda tehlikeli atıkların bertaraf edilmesi için bir tesis bulunmadığı bildirilmiştir [13]. Mevcut sistemin yetersiz kalması nedeni ile hem hava

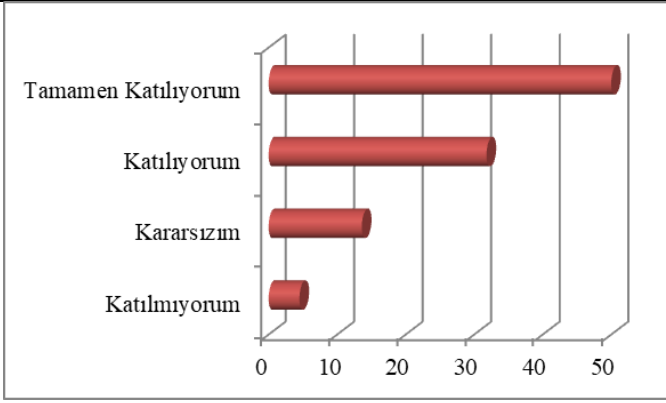

B. Soru 15: Ters lojistik uygulamaları çevre kirliliğini en aza indirme açısından faydalıdır.

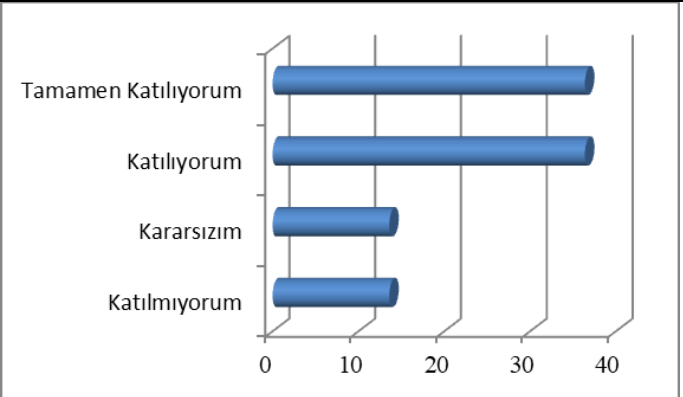

D. Soru 21: Ters lojistik uygulamaları işletmeleri çevresel açıdan daha etkin olmasını sağlar

kalitesi hem de yeraltı sularının kalitesinin olumsuz etkilenmesine neden olmaktadır. Bu sorunlar kapsamından bakıldığında tersine lojistik faaliyetlerinin faydaları, uygulanma sebepleri ve düzenli hale getirilmesi ile birlikte hem geri kazanım ile maliyetlerin azalmasına hem de çevresel atıkların değerlendirilmesi ile birlikte hava-suenerji kaynaklarında kalite artışına neden olacağı bilinmektedir. Karabük ili için yayınlanan raporda 5 haziran Dünya Çevre günü Etkinlikleri kapsamında 2016 yılında ilk ve orta öğretim kurumlarına ziyaretler düzenlenerek çevre bilinci kazandırılmaya çalışıldığ belirtilmiştir. Ancak işletmelere yapılan anket kapsamında ve rapor da belirtilen atık toplama-depolama tesislerinin ve aynı zamanda yasal düzenlemeler hakkında bilgilendirmenin yetersiz olduğu sonucuna varılmıştır. Ayrıca toplanan atık yapısına bakıldığında sadece metal atıkların yönetimi konusunda çalışmalar mevcut iken diğer katı atıkların toplanmasında yetersiz kalındığı bu sebeple atık yönetimi kapsamında çalışmaların yayılması gerektiği kanaatine varılmıştır. 2018 yılında Kardemir A.Ş. tarafindan büyük bir çevre yatırımı yaparak özellikle hava kirliliği için bir çözüm oluşturmaya teşvik ettiği de bilinmektedir. Özellikle son bölümde yapılan frekans analizi sonuçlarına bakarak tersine lojistik uygulamalarının desteklenmesi işletmelerin çevreci politikasında artışlar ile birlikte sürdürülebilir kaynak ve enerji bakış açısını kazanacağı da söyleyebiliriz. 
Gelecek çalışmalarda pilot bölge seçilen Karabük ili için yapılan çalışmanın kapsamı Türkiye Demir-Çelik sektörü genişletilerek tersine lojistik çalışma alanı ile birlikte atık yönetimi konusunda genel bir fikir ve yargıya varılabilir. $\mathrm{Bu}$ çalışmamızda bazı sorularımızın demir-çelik sektörü için uygun olmadığını belirledik. Bu sebeple anket ölçeği demirçelik sektörüne uyarlanarak yeterli derecede bilgi çıkarımı yapılabilir. Geliştirilen yeni anket özellikle bu sektörde ağırlık kazanan Batı Karadeniz Bölgesinde Zonguldak, İsdemir ve Marmara Bölgesi nde faaliyet gösteren işletmelerde eklenerek yeniden değerlendirilebilir.

\section{KAYNAKÇA}

[1] H. Pourmohammadi, M. Rahimi, M. Dessouky, "Sustainable reverse logistics for distribution of industrial waste/byproducts: A joint optimization of operation and environmental costs", Supply Chain Forum: An International Journal, Vol: 9, No:1, 2-17, 2008

[2] S. Dowlatshahi, "Developing a theory of reverse logistics", Interfaces, Vol: 30, No:3, 143-155, 2000

[3] J. R. Stock, "Reverse Logistics in The Supply Chain" Global Purchasing \& Supply Chain Strategies, 44-48, 2001

[4] M. P. De Brito, and R. Dekker, "A framework for reverse logistics“, Berlin Heidelberg, Springer, 3-27, 2004

[5] H. R., Lourenço and P. Soto, "Reverse logistics models and applications: A recoverable production planning model"
Document de Treball, Working paper \#3, Grup de Recerca en Logistica Empresarial, 2002

[6] S. Kumar, S., V. Putnam, "Cradle to cradle: Reverse logistics strategies and opportunities across three industry sectors" Int. J. Production Economics, 115, 305- 315, 2008 [7] http://celik.org.tr/bilecik-demir-celik-a-s/, Erişim tarihi: 01.12.2016 (son erişim tarihi 03.05.2019 olarak bildirilmiştir.)

[8] B. F. Giannetti, S. H. Bonilla, , C. Almeida, "An emergybased evaluation of a reverse logistics network for steel recycling" Journal of Cleaner Production, 46, 48-5, 2013

[9] T. Spengler, H. Puchert, T. Penkuhn, O. Rentz, "Environmental integrated production and recycling management" European Journal of Operational Research, 2, 308-326, 1997

[10] S. Asar, "Tersine Lojistik Faaliyetleri: Erzincan Ve Erzurum İllerinde Bir Uygulama" Yüksek Lisans Tezi, Atatürk Üniversitesi, Erzurum, 2017

[11] N. Bayram, "Sosyal Bilimlerde SPSS ile Veri Analizi" Bursa: Ezgi Kitapevi, S: 194, 2012

[12] A. H. İslamoğlu, Ü. Alnıaçık, "Sosyal Bilimlerde Araştırma Yöntemleri” İstanbul: Beta Yayıncılık, S: 278, 2013

[13] Karabük İli 2016 Y1lı Çevre Durum Raporu, 2016, (http://docplayer.biz.tr/5958892-T-c-karabuk-valiligi-ilcevre-ve-orman-mudurlugu-karabuk-il-cevre-durumraporu.html, (Kayıt Erişim Tarihi: Mayıs, 3, 2018) 